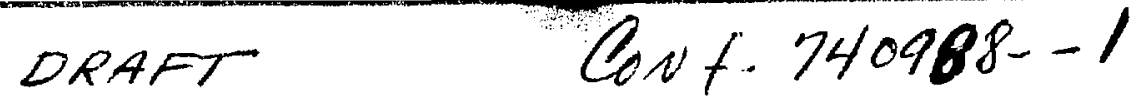

RESULTS ON INCOLOY 800 AND ALLIED STEAM GENERATOR MATERIALS IN

FLORIDA FIELD CORROSION TESTS*

Joseph P. Hammond, P. Patriarca, G. M. Slaughter, and W. A. Maxwe11t

Metals and Ceranics Division, Oak Ridge National Laboratory.

Oak Ridge, Tennessee 37830

ABSTRACT. The corrosion characteristics of similar- and dissimilar-metal weldments in Incoloy 800 and various nickel-base alloys for use in advanced gas-cooled nuclear steam generators were tested in 1sothermal exposures in dynamic steam at 1100 and $1200 \mathrm{~F}$ (595 and $650 \mathrm{C}$ ) for periods to $16,000 \mathrm{~h}$ (2 years). Cursory examinations were made on a limited number of weldment specimens after exposure to $27,000 \mathrm{~h}$. Twelve alloy combinations, in which base metals having good high-temperature properties (1.e., Inconel 625 , Hastelloy $\mathrm{X}$, and IN 102) were Joined to Incoloy 800 (a material having attractive intermediate-temperature properties) and to themselves, were examined in the surface-ground condition. Three high-temperature alloys and Inconel 82 were employed as filler metals. To assess the effects of surface condition, the dissimilar-metal weldments and nonwelded specimens In the various base metals were also tested after being electropolished to eliminate worked surfaces.

General corrosion was determined by weight-galn, weight-loss, and scale thickness measurements, and preferential attack in fuston-1ine areas was assessed by metallographic means. Projected long-time corrosion amounts were very small $\left(<11 \mathrm{mg} / \mathrm{cm}^{2}\right.$ in 20 years) for all the weldments tested except those in Inconel 600 , and for this weldment the projected corrosion was only

*Research sponsored by the U.S. Atomic Energy Commission under contract with the Union Carbide Corporation.

tSouthern Nuclear Engineering, Inc., Dunedin, Florida. 
$4.3 \mathrm{mg} / \mathrm{cm}^{2}$ after 20 years. No evidence of aggravated attack at fusion Iine areas was disclosed. These findings appear to be applicable to weldments In the same alloys exposed to steam at lower temperatures. 


\section{RESULTS ON INCOLOY 800 AND ALLIED STEAM GENERATOR MATERIALS IN FLORIDA FIELD CORROSION TESTS*}

J. P. Hawmond, P. Patriarca, and G. M. Slaughter

Metals and Ceramics Division, Oak Ridge National Laboratory Oak Ridge, Tennessee 37830

\section{W. A. Maxwe11}

Southern Nuclear Engineering, Dunedin, Florida 33528

\section{INTRODUCTION}

Oak Ridge National Laboratory (ORNL) in collaboration with Southern Nuclear Engineering (SNE), Dunedin, Florida, began developing field testing facilities at the Florida Power Corporation's Bartow plant for evaluating materials for steam generators in 1966. Of several test programs completed or current involving simulated-type corrosion studies in superheated steam, intermittent superheated and saturated steam, and in bolling water under heat transfer, two have dealt prominently with Incoloy 800 . The first of these related to extended isothermal general corrosion in superheated steam at 1100 and $1200 \mathrm{~F}$ (595 and $650 \mathrm{C}$ ) and $900 \mathrm{psi}$ pressure that were conducted to examine various similar- and dissimilar-metal welds for an advanced gas cooled reactor application. ${ }^{1}$ The second related to chloride stress corrosion cracking (SCC) tests that were conducted under cyclic steam conditions [between 800 or $700 \mathrm{~F}(425$ or $370 \mathrm{C})$ and $540 \mathrm{~F}(280 \mathrm{c})$ at 900 psi pressure] on a variety of materials as weldments and base metals ${ }^{2}$ to determine resistance to cracking under alternating wetdry (dry-rot) conditions that sometimes occur in steam generators. ${ }^{3,4}$ Whereas the details of the equipment and procedures used in these studies as well as some of the findings have been reported, ${ }^{1,2}$ still

*Research sponsored by the U.S. Atomic Energy Commission under contract with the Union Carbide Corporation. 
other results are unrepurted. We will present here the highlights of our findings on the steam corrosion characteristics of Incoloy 800 in relation to other contemporary materials generally considered for steam generator use.

\section{EXPERIMENTAL TECHNIQUES}

\subsection{Preparation of Specimens}

The chemical analyses of the base metals and filler metals employed In the weldments are given in Table 1 , and those of alloys from which the nonwelded specimens were prepared in Table 2.

Two types of test specimens were used for evaluating SCC (1) conventional $\mathrm{U}$-bends, usually taken from weldments prepared in plate stock, and (2) C-configuration specimens cut from weldmerts made in tubular stock. The latter was intended to more closely represent the geometry and welds involved in steam generators.

The plate weldments from which the U-bends were prepared were made from 1/2-in. thick, hot-rolled, descaled and annealed plates while the tubular weldments were generally made from $3 / 4$ in. $0 D \times 1 / 16$ in. wall tubes in the mill-annealed condition. Butt welds were performed by an automated gas tungsten-arc process, using 16 passes per weld for plates and a single pass for tubes, Welds in the plates were made normal to the plate rolling direction whereas welds in the tubes were longitudinal. The joint preparation consisted of a 100-degree V-groove for the former and a 90-degree one for the latter. Root and bore passes were performed with welding parameters selected to provide a base metal dilution of $50 \pm 10 \%$ to simulate welds in steam generator tube-to-tube and tube-to-tubesheet joints. 
In preparing specimens from plate weldments, strips measuring $31 / 4 \times 1 / 2 \times 1 / 16$ in. were machined out normal to welds. The Cconfiguration specimens were made simply by sawing a 1/16-in. wide slot lengthwise of tubular weldments diametrically opposite to the weld deposit. Pleces $7 / 16-i n$. long were then cut along the axis of the tube.

Strips were mounted as U-specimens by bending in a press and die set to an inside radius of $1 / 2$ in. and the slot in the $\mathrm{C}$-specimens opened to a 1/4 in. gap while mounting on an H-rail. The U-bend was strained $6.2 \%$ as mounted (outside surface at weld) and the c-specimen $0.9 \%$ (Inside surface at weld).

For studies on U-bend specimens, four basic surface conditions were Investigated, namely (1) ground on a 100-mesh-grit belt, (2) ground and annealed, (3) ground, annealed, and pickled, and (4) as-received (when as sheet). Strip specimens ground on the 100-mesh belt had their edges similarly finished, but edges on asreceived sheet specimens were ground thiough a 400-mesh belt to remove effects from shearing used to cut the sheet.

The tubular, C-specimens were evaluated for an equal latitude of finishes and conditions and these will be enumerated as the results are reviewed. Edge surfaces on these specimens were alike, all ground through 400 grit on a Speedlap machine.

After test, the amount of elastic springback accompanying dismount was determined. This and initial springback were used to estimate the extent of stress relaxation accompanying exposure.

\subsection{Steam Corrosion Facilities}

The general corrosion (scaling) and stress corrosion cracking studies were conducted in high-pressure loops with auxillary control 
facilities that were quite similar. Figure 1 illustrates the facilfty useu for the SCC tests. Steam emerging from a Bartow superheater is Introduced in the loop at a pressure of $900 \mathrm{ps} 1$ and $700 \mathrm{~F}(370 \mathrm{C})$. Four legs of heaters upstream of the top of two autoclaves and two between the top and bottom autoclaves enables operating the two test sections at selected temperatures elther in unison or separately. The autoclaves, which are 12-ft-long and 1.9-in. ID are controllable over the test region (about $8 \mathrm{ft}$ ) to $\pm 50 \mathrm{~F}$.

The SCC facility (FIg. 1) Incorporates means for separately Introducing oxygen (as gas) and Nacl (saline solution) at the top of the loop as well as provisions for monitoring the contaminants at the drain.

Type 316 stainless steel piping and 1ike filler metal was used to fabricate the high-pressure loop for the general corrosion facility while the cilloride SCC 10op was fabricated of Incoloy 800 using Inconel 82 filler metal.

\subsection{Water and Steam Chemistry}

The superheated steam employed in the general corrosion and SCC tests was basically the same and of high commerclal quality. Details of the water and steam control practices at Bartow were published previously. ${ }^{1}$ The pH of the botler water was controlled at around 10.4 by a coordinated phosphate treatment and the saturated steam around 8.9. The aqueous medium used for injection NaCl

into the SCC loop (FIg. 1) consisted of superheater condensate. It showed an average $\mathrm{pH}$ of $\mathbf{8 . 4}$ during the test period, with a conductivity around 3.3 micromhos and suspended solids $<5 \mathrm{ppm}$. 


\subsection{Test Environments}

The general corrosion loop was run continuously during testing except for cooldown at $1000 \mathrm{hr}$ intervals to examine specimens.

Numerous trial runs were made in the SCC loop to establish suitable operating conditions for simulating dry-rot exposures. Because a very low concentration of $\mathrm{NaCl}\left(<0.25 \mathrm{ppm} \mathrm{Cl}^{-}\right.$) proved soluble in dry (superheated) steam at the selected test press re (900 psi), in this particular test program we injected salt in the loop only during the wet (saturation) phase of cycling. However, oxygen was injected continuously.

The loop operating parameters selected for the SCC study were the

\section{following:}

Test cycles

Saturation periods

Superheat temperature, ${ }^{\circ} \mathrm{F}$

Saturation temperature, ${ }^{\circ}$

Oxygen injected, ppm

Chloride injected, ppm three per week between superheated and saturated conditions

$24 \mathrm{hr}$ each, followed by $24 \mathrm{hr}$ at superheat (except $48 \mathrm{hr}$ on weekends).

800 or 700

540

20 max (based on total fluent)

$10 \max$ (based on total fluent)

Assays were made of the oxygen and chloride concentrations during injection at their maximum amounts, both off the floor of autoclaves (where water collected during the saturation phase of cycling) and at positions two-thirds the diametrical distance from the bottom. Average concentrations were:

\begin{tabular}{lcc} 
& \multicolumn{2}{c}{ Concentration, ppm } \\
\cline { 2 - 3 } Top Autoclave & Chloride & Oxygen \\
\cline { 2 - 3 } Top position & 0.11 & 23.1 \\
Bottom position & 44.4 & 10.8 \\
Bottom Autoclave & & \\
\hline $\begin{array}{l}\text { Top position } \\
\text { Bottom position }\end{array}$ & 50.3 & 11.3
\end{tabular}


Figure 2 illustrates the positioning of $\mathrm{U}$ - and $\mathrm{C}-$ specimens in autoclaves and the environments to which stressed surfaces were exposed during cycling. Note the C-specimens were tested in two rows one over the cther. The U-bends and bottom row of $\mathrm{C}$-specimens were exposed alternately to superheated steam and water, whereas the top row of C-specimens were exposed alternately to superheated and molst steam. The steam velovity in the loop was only about $5 \mathrm{ft} / \mathrm{sec}$ thus accounting for the ready collection of condensate on the bottom of autoclaves. This water reaching a height of $0.073 \mathrm{in}$. in one $\mathrm{hr}$ at saturation and $0.093 \mathrm{in.}$ at termination of saturation. The U-specimens and bottom $C$-specimens were mounted 1/16 in. off the floor of autoclaves to enable wetting of test surfaces.

3. EXPERIMENTAL RESULTS

\subsection{Isothermal General Corrosion in Steam}

In gas cooled steam generators for advanced nuclear reactors, it is expected that economic considerations will dictate the use of certain materials at high temperatures, others at intermediate temperature, (for which Incoloy 800 is preferred) and still others at lowest temperature (e.g., $21 / 4 \mathrm{Cr}-1$ Mo stee1). Thus in such systems, similarand dissimilar-metal welds will be exposed to the steam coolant over a range of temperature (900 to $1200 \mathrm{~F})$.

In our study, we examined joints connecting Incoloy 800 with Inconel 625 and Hastelloy $X$ (superior at high temperature) with the latter as filler metal as well as Inconel 82 . Incoloy 800 joined to Itself with Inconel 82, and Inconel 625 and Hastelloy $\mathrm{X}$ foined to themselves with themselves also were appraised. Heldments in Inconel 600 joined to $21 / 4 \mathrm{Cr}-1$ Mo steel with Inconel 82. Weldments in Inconel 600 Jolned to itself with Inconel 82 was included for comparison. 
Of particular concern in this study was the prospect of aggravated scaling attack at fusion line ares, expecially in the dissimilar metal welds. Quantitative appraisals of corrosion were made of weldments as well as base metals after 8000 and $1600 \mathrm{hr}$ at 1100 and $1200 \mathrm{~F}$ (595 and $650 \mathrm{c}$ ) using the weight-gain and to a more limited extent, the weight-loss method of analysis. Assessments of corrosion by weight-loss generally agreed with those made by weight-gain and the latter was qualified as an acceptable, more convenient method of analysis.

The results of weight-gain analyses made on ground similar-metal weldment specimens after exposure for $1600 \mathrm{hr}$ at 1000 and $1200 \mathrm{~F}$ are presented in Table 3 . Using the usual linear equations for extrapolating scaling attack to 20 years in terms of inches of metal penetrated, relatively low levels of corrosion were obtained for all weldments. Incoloy 800 welded to itself indicated only a half mil penetration at $1200 \mathrm{~F}$ and less than two-tenths at $1100 \mathrm{~F}$. The amount of corrosion indicated for the Inconel 625 and Hastelloy X simflar-metal weldments were lower still and that of Inconel 600 somewhat higher.

The effects of grinding specimens on a 100-mesh belt as a surface fintsh proved to have a profound effect on the corrosion response of Incoloy 800 , as compared to electropolishing ground specimens (laying bear the underlying hot-rolled metal structure), as several Investigators in Europe have noted. ${ }^{5,6}$ Figure 3 illustrates this effect on Incoloy 800 and Inconel 600 at 595 and 650 F. Grinding produced vast improvements in corrosion resistance in Incoloy 800 and moderate improvements in Inconel 600 while giving results somewhat inferior to electropolishing in Inconel 625 and Hastelloy $X$.

Although this effect in Incoloy. 800 is well-known and reasonably well understood, what way not be recognized is the tenaciousness 
of the scales that form on electropolished Incoloy 800 and the excellent corrosion responses indicated for them over the long term. Unsuccessful attempts remove the scale formed on electropolished Incoloy witt: varlous descaling solutions in connection with our weight-loss analyses, prompted supplemental tests to appraise the tenacity of these scales. Electropolished specimens exposed to steam for $8000 \mathrm{hr}$ at 100 and $1200 \mathrm{~F}$ were quenched in roomtemperature tap water from the exposure temperature. An examination of the quenching water for traces of oxide and weighings of the specimens before and after quenching showed no perceptible oxide loss.

Because weight-gain data points for electrpolished Incoloy 800 showed essentially no scatter from smooth curves and clearly exhibited nonlinear corrosion rates throughout exposure, a detailed analysis of the data seemed justified. Instead of a constant rate, second stage of corrosion generally depicted for intermediate and high nickel alloys, the data throughout (to $14,000 \mathrm{hr}$ ) conformed to a parabolic equation of the form

$$
W=W_{0}+? /(B+C T)
$$

where

$$
\begin{aligned}
W & =\text { the weight gained, } \\
T & =\text { time, and } \\
W_{0}, B, C & =\text { constants. }
\end{aligned}
$$

Figure 4 show plots of the weight-gain data for electropolished Incoloy 800 exposed at 1100 and $1200 \mathrm{~F}$, respectively, with superimposed corrosion models for the duplicate specimens. ${ }^{\circ}$ Table 4 lists estimates of the equation constants with standard errors for the individual specimens, together with the amounts of corrosion in 20 years calculated with these constants. 
Features characteristic of the corrosion of electropolished Incoloy 800 thus are constantly diminishing rates of corrosion throughout exposure and comparatively large amounts during earlier stages (Fig. 4). Although the amounts of corrosion occurring on Incoloy 800 at 1100 and 1200 F were vastly different in the ground and electropolished conditions after $3000 \mathrm{hr}$ (about 39 and 15 times higher for electropolished at 1100 and $1200 \mathrm{~F}$, respectively), the amounts estimated for electropolished Incoloy 800 after 20 years (Table 4) are comparable with those 1isted for ground Incoloy 800 weldments (Table 3).

Besides the analyses made on Incoloy 800 and associated alloys by the welght-gain and welght-loss methods, appraisals of metal penetration were attempted by the metallographic method. In general, these analyses were not very. quantitative. ${ }^{2}$ Examinations for scaling characteristics and possible froms of aggravated attack, however, were helpful. Examination of dissimilar-metal welds after 800,1600 , and some at $27,000 \mathrm{hr}$ exposure at 1100 and $1200 \mathrm{~F}$ failed to uncover any preferred or abnormally high attack at fuston lines, nor were any alarming instances of pitting or internal scaling noted in base metals or weld deposits. 
- Figure 5 illustrates the character of the scale formed on Incoloy 800 after $8000 \mathrm{hr}$ at $1200 \mathrm{~F}$ : (a) for ground condition and (b) electropolished. Confirming our other analyses, the amount of scale fromed was much greater electropolished. Both conditions showed a uniformly thick component layered to the surface as well as penetrations Into the substrate which were Intergranular in mode. The intergranular protrusions were much bulkier and deeper fro the electropolished condition and four separate oxide phases were readily discerned. Whereas the Information given earlier on calculated depths of metal penetrated in twenty years (based on weight-gain data) was never greater than one mil, it should be noted here that as a result of inner oxide layer, the metal depths actually penetrated were consdierably greater, expecially for the electropolished condition.

\subsection{Chloride SCC in Cyclic Steam}

The same alloy systems examined for Isothermal general corrosion at 1100 and $1200 \mathrm{~F}$ were tested for chloride SCC under the cyclic steam conditions along with several materials of interest for LMFBR application, namely, type 304 stainless steel joined with type 308 and the ferritic steels $21 / 4 \mathrm{Cr}-1 \mathrm{Mo}, 9 \mathrm{Cr}-1 \mathrm{Mo}$, and Super $\mathrm{Cr}$. Both welded and nonwelded specimens were included. Table 5 gives the results for these materials tested 16-18 weeks as $\mathrm{U}$-bends by cycling between 800 and $540 \mathrm{~F}$

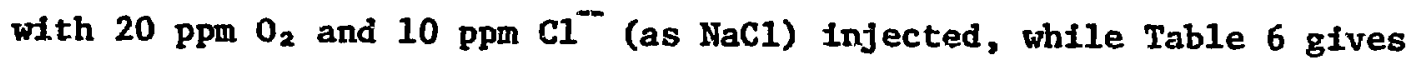
results for C-specimens 
cycled for 24 weeks between 700 and $540 \mathrm{Fith} 8 \mathrm{ppm} \mathrm{\textrm {O } _ { 2 }}$ and $4 \mathrm{ppm} \mathrm{Cl}$. In the latter tests, a holder of U-specimens was included to compare the respective test specimens with the latter levels of contaminants. The tubular, C-specimens in these tests were examined with bore surfaces both as-furnished and ground with 100-grit emory cloth. The tests included both nonwelded and welded conditions along with post-weld annealed conditions (see column 4, Table 6).

A cursory comparison of the C-specimen results (Table 6) with the U-specimen results (Table 5), showed a much greater tendency for the latter to crack. For U-spcimens, all materials cracked to some extent with the exception of welded and nonwelded Inconel 625 and the nonwelded ferritic steels (ferritics tested nonwelded only). U-specimens that cracked to varying degrees, included welded and nonwelded Incoloy 800, Inconel 600, Hastelloy $\mathrm{X}$, and type 304 stainless steel. On the other hand, no C-specimens in welded or nonwelded Incoloy 800, Inconel 600, or Inconel 625 failed but specimens in type 304 stalnless steel joined with type 308 and the welded $9 \mathrm{Cr}-1$ Mo and Super $12 \mathrm{Cr}$ steels that were not appropriately post-weld annealed cracked (Table 6), Welded $21 / 4 \mathrm{Cr}-1$ Mo steel did not crack even with the post-weld anneal omitted.

This higher susceptibility to cracking displayed by U-bend specimens in the environment with higher contaminant levels was ultimately attributed to specimen-associated factors rather than to environment. That environment of the C-specimen run was probably 1ittle less severe than the $U$-bend run is attested to by the fact that the ground U-bend specimens in welded Incoloy 800 and type 304 stainless steel that were incorporated in the C-specimen run for comparing the 
two specimen types, showed little less tendency to crack than they did in the U-bend run (compare group $1 U$ and $2 U$, Table 6 with groups 1 and 4, Table 5). That the difference in response rather is attributable to specimen-associated factors is indicated by the fact that the same alloy systems that resisted cracking as C-specimens (ground specimens of welded Incoloy 800, type 304 stainless and to a large extent Hastelloy X), cracked rather severely as U-bends (Table 5). Two factors are believed responsible for this (1) the fact that $U$-bend specimens were prestrained to a substantially higher level (6.2\% vs 0.9$)$ and (2) graln structures of heat-affected zones were considerably coarser for the U-bends. Several investigators have found plastic straining to accelerate cracking time in stainless steels up to levels of $20 \%$ cold work $9,10,11,12$. Hines, ${ }^{13}$ working with $18-8 \mathrm{~T}$; wires in boiling $52 \% \mathrm{MgCl}_{2}$, found $7 \%$ prestrain (U-bends were strained $6.2 \%$ ) to give lowest cracking time. The coarseness of grain structures was though significant since cracking in U-bend specimens (Table 5) usually occurred intergranularly, in weld heat-affected zones. qther significant observations made from the U-bend tests were the following. - It was found that all alloys invariably showed a greater propensity to fall when welded than nonwelded. This, however, is not unexpected. of severalseveral surface conditions examined, the ground by far promoted highest susceptibility to cracking. Hastelloy $X$ welded with Hastelloy $X$ and Inconel 600 joined with Inconel 82 cracked in the ground condition but never in the ground and annealed condition. Cracking in Incoloy 800 welded with Inconel 82 and this material nonwelded also stongly favored the ground condition over the ground and annealed. These findings agree with the work of Cochran and Staehle, ${ }^{30}$ who found that specimens of Fe-NI-Cr alloys with a rough mechanical polish have one-fourth the mean cracking times of vacuum-annealed specimens in boiling $42 \% \mathrm{MgCl}_{2}$.

From the C-specimen tests (Table 6) the following may be concluded (1) weldment specimens in $21 / 4 \mathrm{Cr}-1$ Mo steel appear to resist 
cracking without the benefit of post-weld annealing, (2) $9 \mathrm{Cr}-1 \mathrm{Mo}$ steel weldment specimens crack as welded but resist cracking when post-weld annealed in a seemingly broad temperature range below the lower critical temperature, and (3) specimens in welded Syper 12 Cr resist cracking provided annealing is performed in sufficient proximity to the lower critical. Specimens in Super $12 \mathrm{Cr}$ as welded were not tested as they were too stiff to mount without cracking.

Figure 6 illustrates the nature of the cracking in U-bend specimens of Incoloy 800 welded with Inconel. 82. As in most cases of weldment U-specimens, cracking initiated in the weld heat-affected zone on the root size, where grains were coarsest. Cracking continued in the heat-affacted zone and generally did not encroach appreciably on the weld deposit [FIg. 6(b)]. This resistance displayed by Inconel 82 weld deposit was common also to the Inconel 600 weldment. As noted earlier, cracking in the heat-affected zone was generally intergranular but tended to be transgranular in Incoloy 800 when it Infrequently strayed into the adjoining fine-grain base metal. [Fog. 6(b)]. The cracking velocity. In specimens of Incoloy 800 welded with Inconel 82 (group 1) appeared to be significantly lower than for specimens of type 304 stainless steel welded with type 308 (group 5). 
U-bends Cycled between 800 and $530 \mathrm{~F}, 18$ weeks:

$\begin{array}{ll}21 / 4 \text { Cr-1 Mo steel } & 68 \% \\ \text { Incoloy } 800 & 79 \% \\ \text { Inconel } 600 & 80 \% \\ \text { Inconel } 625 & 88 \%\end{array}$

C-specimens Cycled between 700 and 540 F, 24 weeks:

$\begin{array}{lr}21 / 4 \mathrm{Cr}-1 \text { Mo steel } & 99 \% \\ \text { Incoloy } 800 & >99 \%\end{array}$

Because the test surface in the U-bends were probably work hardened to a considerable extent ( $6.2 \%$ total stra1n), stress levesl in a11 cases doubtlessly were adequate for tests.

It is apparent from our tests that the degree of chloride cracking susceptibility displayed by an alloy may vary greatly with rather undramatic differences in test specimens. Wheras weldments in Incoloy 800 foined with Inconel 82 exhibited a rather high cracking susceptibility in the chloride, cyclic steam enviroment when tested as $\mathrm{U}$-bends, it totally resisted cracking as C-specimens, Since type 304 stainless steel joined with type 308 showed a rather high susceptibility for cracking as C-specimens, It is evident that Incoloy 800 represents a definite improvement over type 304 stainless steel for welded components to see service in chloride-contaminated, cyclic steam environments. The good general corrosion resistance desplayed by Incoloy 800 in 1100 and $1200 \mathrm{~F}$ steam both as ground and electropolished, couples with the fact that dissimflar-metal welds in it showed no evidence of appravated or localized attack after prolonged periods at these temperatures also reflects encouragingly on Insoloy 800 .

Stresses relaxed to a greater degree in the U-bend specimens, but because their test surfaces work hardened considerably (6.2\% strain), stress Jevels in all cases doubtlessly were adequate. 
DISCUSSION AND CONCLUSIONS

The degree to which specimens retained stress during cyclic testing was assessed by comparing the elastic springback at dismount with and without exposure. By assuming that the extent of stress relaxation was proportional to loss of springback, the following approximate percentages of stress retained. by several of the alloys were obatined:

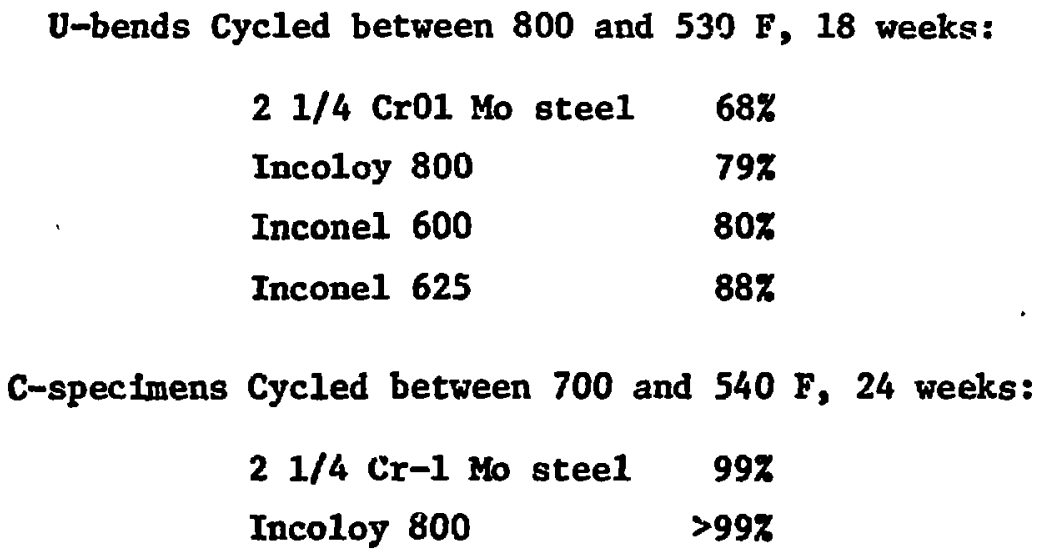

Stresses relaxed to a greater degree in the U-bend specimens, but because their test surfaces probably work hardened considerably (6.2\% strain), stress levels in all cases doubtlessly were adequate.

Our tests have shown Incoloy 800 both nonwelded and welded to have a definite susceptibility to chloride SCC in the cyclic steam enviroment where the test conditions were deemed severe. However, in constantdeflection tests where the test surface was strained a minimal amount and the weld heat-affected zone was not as prominent (c-type specimens) nonwelded and weld Incoloy 800 completely resisted cracking ( 0 falled of 24) whereas nonwelded and welded type 304 stainless steel gave numerous faflures (14 of 24). 
Appraisals of the isothermal general corrosion of Incoloy 800 in steam at 1100 and $1200^{\circ} \mathrm{F}$ gave short-term results that were widely different depending upon the surface finish. Whereas the electropolished condition resulted in much greater amoungs of corrosion in eazller stages as compared to ground, the corrosion with time was parabolic in form and after twenty year calculated amounts of corrosion were little different for the two conditions, less than $7 \mathrm{mg} / \mathrm{cm}^{2}$ weight gained or $15 \mathrm{mg} / \mathrm{cm}^{2}$ metal consumed. The good general corrosion resistance displayed by Incoloy 800 together with the freedom from localized attack exhlbited for its welds is encouraging. However, its use in steam environments where chloride SCC is a threat must be guarded since under the more severe condition ir can crack. 


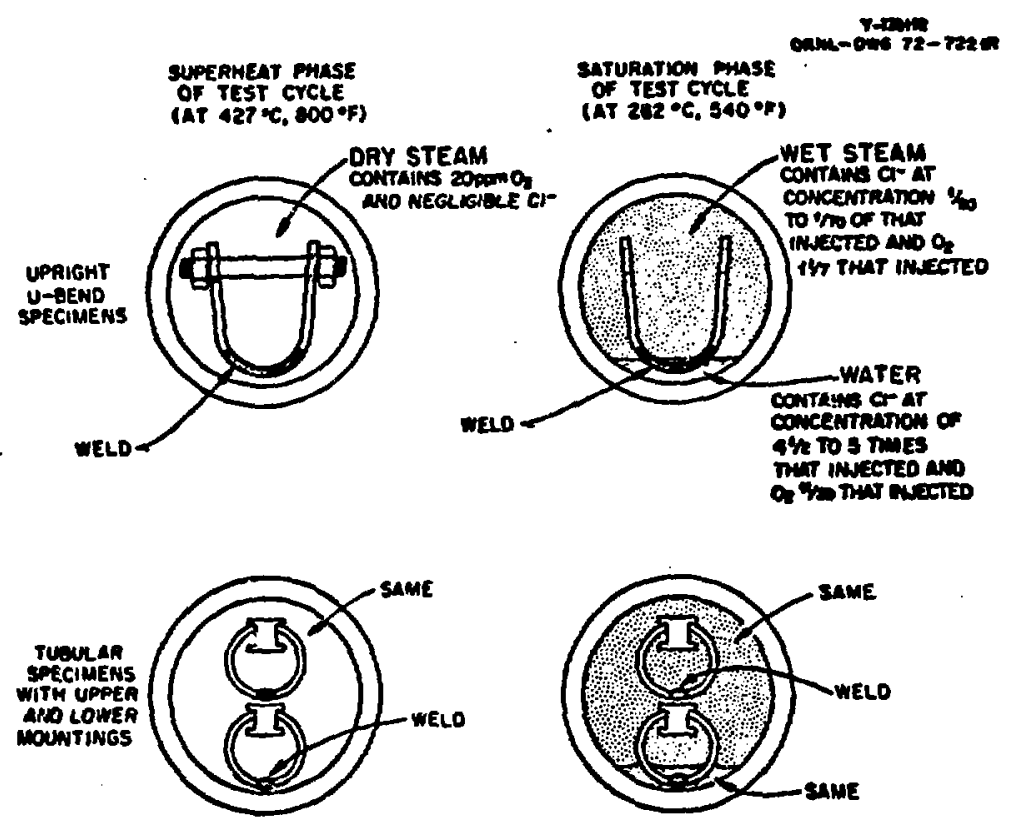

20 nOM OXYGEN IS InUECTEO CONTMUDUSLY

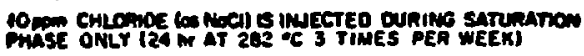

F18. 2. Schematic Showing Specimens and Environmental Conditions During Cyclic Test. 


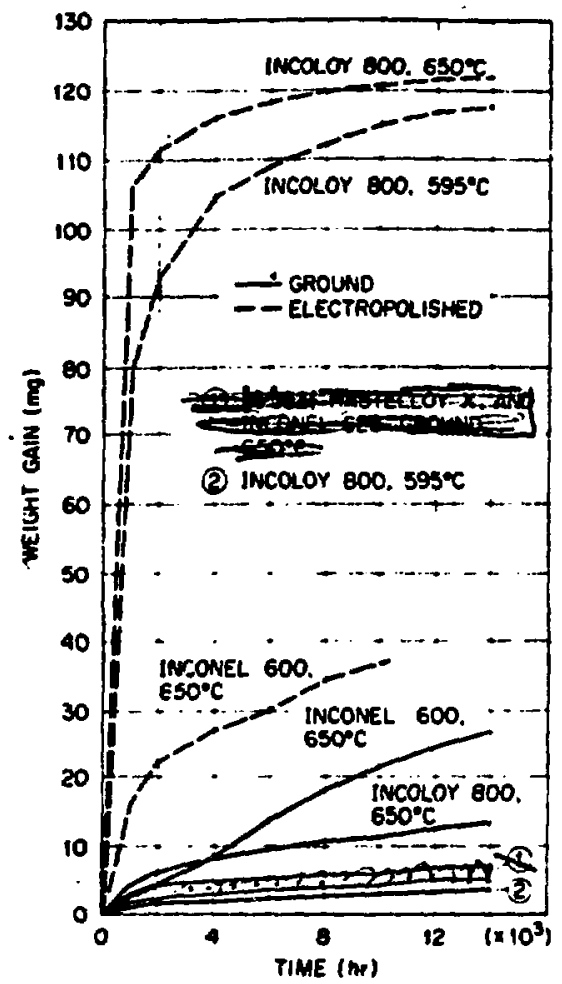

Fig. 3. Total Weight Gain of Incoloy 800 as Ground and Electropolished in Comparison with Other Base Metals. Curves are drawn through averaged values for duplicate determinations. Specimen surface area was $20 \mathrm{~cm}^{2}$. 

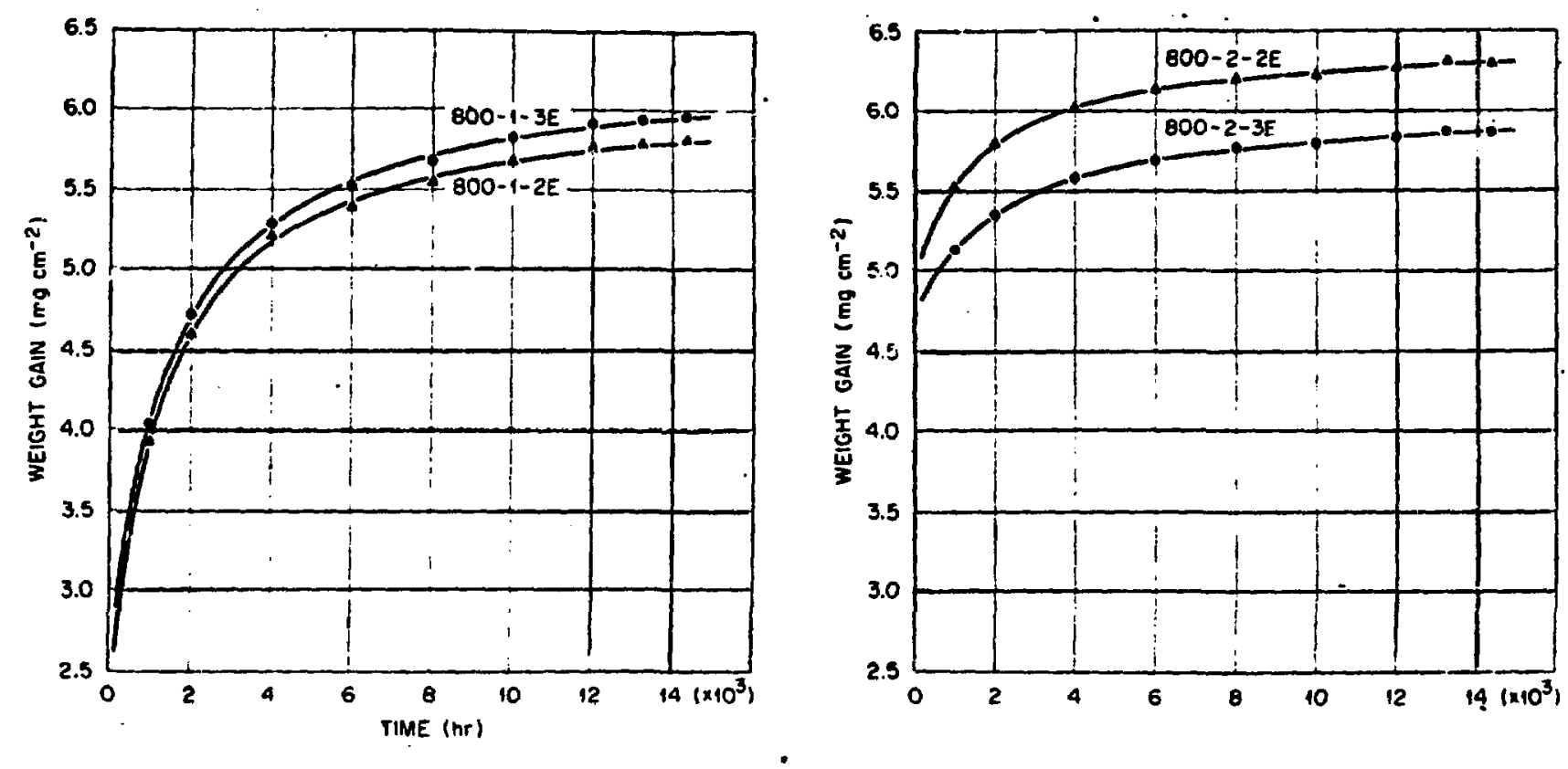

F1g. 4. Corrosion of Electropolished Incoloy 800 in Steam at $1100 \mathrm{~F}$ (Left) and $1.200 \mathrm{~F}$ (Right). 


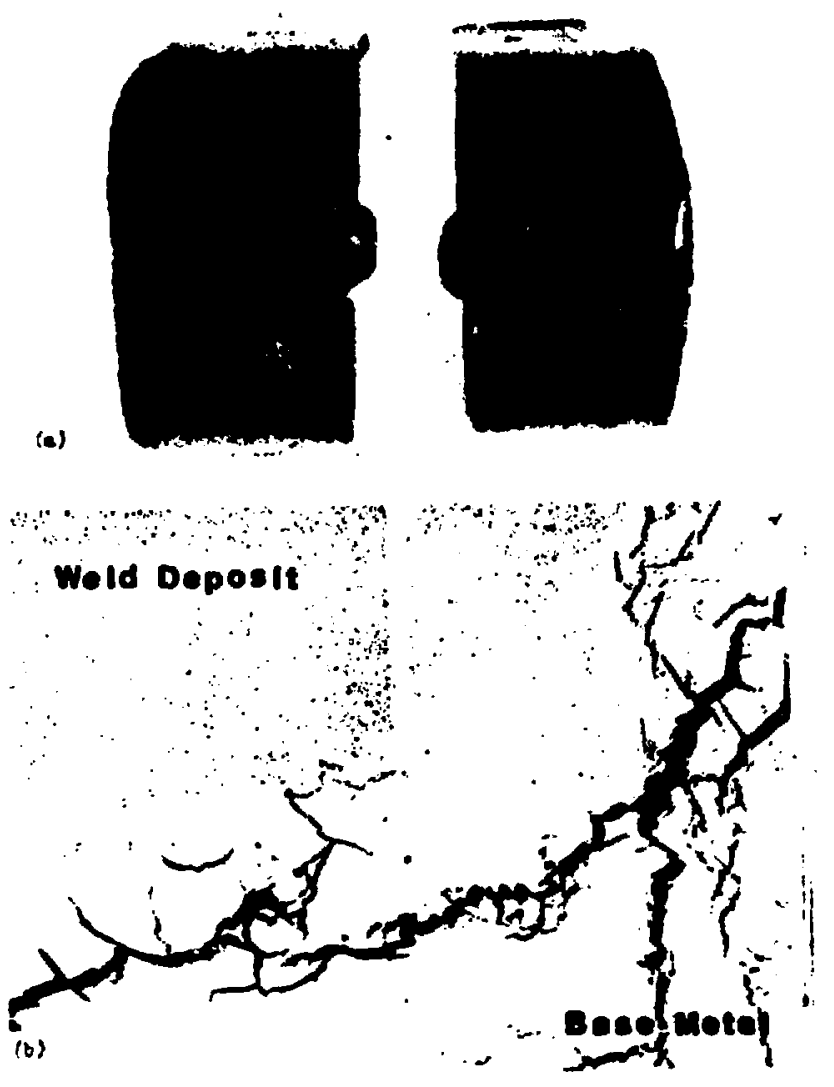

F1g. 5. Characteristics of Chloride SCC in Incoloy 800 Welded with Inconel 82. (a) U-bend specimens after fallure. (b) Structural features at arrow in (a). Etched with $\mathrm{H}_{2} \mathrm{O}_{2}-\mathrm{HCl}$ mixture. 